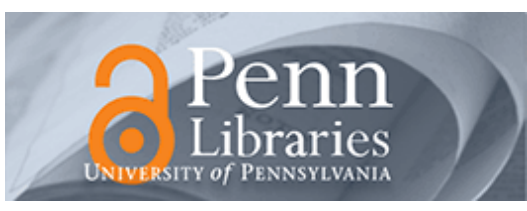

University of Pennsylvania
ScholarlyCommons

Departmental Papers (ASC)

Annenberg School for Communication

2018

\title{
A Bookmobile Critique of Institutions, Infrastructure, and Precarious Mobility
}

Jessa Lingel

University of Pennsylvania, jlingel@asc.upenn.edu

Follow this and additional works at: https://repository.upenn.edu/asc_papers

Part of the Communication Commons

\section{Recommended Citation}

Lingel, J. (2018). A Bookmobile Critique of Institutions, Infrastructure, and Precarious Mobility. Public Culture, 30 (2), $305-327$. https://doi.org/10.1215/08992363-4310942

This paper is posted at ScholarlyCommons. https://repository.upenn.edu/asc_papers/707

For more information, please contact repository@pobox.upenn.edu. 


\section{A Bookmobile Critique of Institutions, Infrastructure, and Precarious Mobility}

\section{Disciplines}

Communication | Social and Behavioral Sciences 


\section{A Bookmobile Critique of Institutions, Infrastructure, and Precarious Mobility}

Jessa Lingel

There is a mismatch between what libraries do and how they are perceived, between how they are used by local patrons and how they are used as punch lines in conversations about civic resources and technological change. In the United States, public libraries have been woven into the social and spatial fabric of neighborhood life, whether urban, suburban, or rural, and they enjoy immense popularity: According to a 2014 study from the Pew Research Center (2014), 54 percent of people in the United States use a public library each year, 72 percent of people live in a household with a regular library user, and libraries are viewed as important community resources by 91 percent of people. As library historian Wayne Wiegand (2011) has repeatedly pointed out, there are more public libraries in the United States than there are McDonald's. From a purely statistical viewpoint, the local library could be considered just as successful and as endemic to US social life as the Big Mac.

Beyond their popularity, libraries are increasingly crucial as a space set aside for public use. Even as libraries continue to fulfill their traditional roles of offering references, services and reading materials, they also fill in gaps left by the disappearance of and lack of investment in other institutions (Mattern 2014). Instead of employment agencies, people use libraries to search for jobs and learn new skills, ranging from digital literacy to English as a second language. By offering programming, libraries have become de facto day care centers and after- school programs, as well as public meeting spaces for affinity groups and civic organizations. Both the scarcity of public space and the multiple services provided therein make libraries a vital public institution.

Yet libraries do not seem crucial to an increasing number of lawmakers, journalists (see Doctorow 2010), and commenters (see Losowsky 2013). In these viewpoints, libraries are renarrated from a community resource for doit- yourself (DIY) education and sustaining local (economic, educational, cultural) interests to a waste of taxpayer dollars. Despite the fact that libraries make serious interventions of social welfare, they are regularly dismissed as technologically obsolete, economically unviable, and institutionally irrelevant. I want to reclaim both the necessity and the vibrance of libraries by looking at one of its most extracurricular and certainly least grounded initiatives: bookmobiles.

The first time I saw a bookmobile, I was in elementary school. As the converted school bus pulled into the playground, I watched perplexed, not really comprehending the claim "Alameda County Public Library" written on the bus's side. Students were herded onto the bus in groups, and I ambled along seat aisles made into bookshelves. My main memory is of uncanniness - the familiar barcodes and library stamps in the unfamiliar setting of a school bus and the semi- scandalous feeling of moving around an unmoving vehicle. The simultaneous sense of a stable institution made to move, recognizable artifacts unmoored and relocated, is, I argue, fundamental to bookmobiles. I see library initiatives involving bookmobiles as assemblages that allow us to ask, what happens when libraries become mobile, navigating obstacles both social and spatial? Particularly in contexts of crisis, what can moving libraries reveal of broader relationships to infrastructure, institutions, and mobility?

In some ways, bookmobiles are an obvious assemblage for asking how institutions of long- standing stability make themselves flexible, and yet critical interrogations of the bookmobile remain rare (for an important exception, see Attig 2014). When I have spoken casually and to nonlibrarians about bookmobiles, responses typically range between wonder, amusement, and cynicism, with bookmobiles being labeled as cute, quaint, and largely performative gestures from an increasingly obsolete institution. The perceived near demise of libraries (see MIT Technology Review Staff 2005), often coupled with a tendency to delegitimize library work through objectifying or sexualizing librarians (Radford and Radford 1997), likely contributes to this dismissal of bookmobiles, a reluctance to take them or their host institutions seriously in discourses of technology and infrastructure.

I echo classic library and information science theorist Jesse Shera's (1970) conviction that libraries are sites of social and structural communication and that in looking at how institutional actors fit into sociotechnical fabrics of people and infrastructure, libraries are profoundly instructive. I see bookmobiles as tactical assemblages of people, media, and vehicles. The institutional mobility of bookmobiles draws together, communicates, and enables communication between technologies, people, and spaces. In the following pages, I unpack the different facets of this communication work more deeply. To do so, I consider the tactical and strategic relationships (de Certeau 1984) 
between bookmobiles and larger structures, looking at the mediant edges (Appadurai 2015) within these networks in terms of mobility, language, materiality, and memory.

I have opened this essay with a discussion of US libraries, but there are thousands of bookmobile projects operating across the globe, with transport methods that range from semitrucks (Batchelder 2015) to school buses (Dar 2014) to donkeys (IFLA 2002). Bookmobiles have historically been motivated by a desire to bring services to people beyond the reach of the library's brick- and- mortar base (Brown 1967; Sexton 1961). Rural areas tend to come to mind first in thinking about where bookmobiles operate, yet they have also long been of service in urban and suburban neighborhoods (Elton 2015). Crucially, both the material form of and attitudes toward bookmobiles vary from place to place. I concentrate on two bookmobile initiatives, the first in Port au Prince, Haiti, and the second in Haifa, Israel. Both operate in circumstances of precarity and tension, contexts that highlight the political, social, and cultural elements of mobile institutions in uncertain infrastructure.

I set out to study bookmobiles in Haiti because of its extremely precarious infrastructure. On learning about a bookmobile project based in Port au Prince, I saw an opportunity to investigate libraries, mobility, and precarity and to think about how institutions make themselves mobile in contexts of intense and multifaceted uncertainty. I originally conceived of this project as a single case study, but when I had the opportunity to engage with Palestinian bookmobile librarians, I realized that I could offer a comparative study with a more nuanced understanding of crisis. As is often lamented in the information and communication technologies for development (ICT4D) literature (Finn and Oreglia 2016; Mazzarella 2010; Sheller 2013), crisis is too frequently conceptualized as a momentary, temporal state of exception, eliding more gradual and systemic circumstances of crisis. ${ }^{1}$

A more conventional understanding of crisis describes Port au Prince better than Haifa; the former is the capital of an extremely poor country where longstanding infrastructural fragility was compounded by the incredible destruction of an earthquake in 2010. Yet experiences of crisis are felt deeply by Palestinians, including those who live in Israel, those who live in the West Bank and Gaza, and those in the global diaspora. As Helga Tawil-Souri (2011: 68) argues, in her investigation of technological infrastructures of surveillance and control by Israel over Palestinians: "The Israeli state practices, and arguably perfects, a logic of territorial and population control and monitoring. One form is high- tech: unmanned aerial drones, $\mathrm{X}$ - ray machines, remote- controlled cameras, radars, and surveillance techniques that instill fear and awe; another form is physically and geographically violent: walls, fences, checkpoints, turnstiles, settlements, bypass roads, fighter jets, bulldozers, and machine guns." Everyday life for Palestinians requires constant surveillance, uncertainty, and discrimination. Without wanting to delve too deeply into the fraught and complex history of Palestinian- Israeli conflict, I think it would be fair to say that both Haitians and Palestinians often see themselves as continually under a threat of crisis.

In both Port au Prince and Haifa, the precarity experienced by Haitians and Palestinians has come to be baked into the practices and spatial movements of everyday life. Expectations of social interactions; schedules, delays, and workarounds; the (in)ability to move people and things — all are inflected with localized understandings of shifting political realities. These political realities are often infrastructural, and in the remainder of this essay I draw on bookmobile initiatives launched in circumstances of political and spatial uncertainty as a way of thinking about mobile technology not in terms of cell phones or tablets but in the literally mobile movement of technological resources, media, and information.

\section{Bookmobiles, Tactility, and Reimagined Infrastructure}

Bookmobiles are a strikingly literal example of institutions on the move. Although we may recognize that institutions are not monolithic entities but rather shifting compositions of people, processes, and technologies (see Douglas 1986), we have few models for thinking about institutional flexibility in a precise and concrete way (Sheller and Urry 2003). Bookmobiles offer a case study for examining institutional mobility and decentralization, terms that are increasingly associated with globalization and postindustrialization. What if, instead of considering crowdsourced labor and artificial intelligence workforces (Irani and Silberman 2013; Zyskowski et al. 2015), we looked to bookmobiles as examples of fragmented, highly mobile institutions? What can the political work of bookmobiles show us about institutions (and infrastructures) in flux? 
In bookmobiles I see a convergence of infrastructure, mobility, technology, and people, assemblages that open up questions that are as relevant to science and technology studies, communication studies, and mobility theory as they are to library science. What do bookmobiles reveal about the relationships between institutions and infrastructure? I ask this question less in terms of the services these bookmobiles provide (such as education, information, entertainment, community) and more in terms of how people make sense of and value libraries as social institutions that navigate complex infrastructures. And further, when libraries become mobile, what meanings and values surface in bookmobiles as sociotechnical assemblages? To what extent can we use bookmobiles as a means of understanding assemblages and infrastructure in connections between people, things, and space?

In contrast to policy- oriented research that focuses on the efficacy of global development initiatives in terms of discrete goals and deliverables (Mazzarella 2010), my goals here are at once broader and narrower. Rather than determining the instrumental value of specific bookmobile projects, I use them as a reference point for evaluating infrastructural politics and institutional fragmentation. As mobile libraries, bookmobiles are uniquely situated to bring into relief convergences between mobility, language, memory, and infrastructure. In turn, these convergences offer a critique of institutional fragmentation and decentralization. The bookmobiles that I describe below operate in a particular context of crisis, which both shapes their operations and sharpens their relationships to infrastructure.

Before describing these bookmobile initiatives in depth, I want to make some terminological clarifications. When I refer to institutions, I mean the corporate and civic entities that provide and sell services, where "institutional structures [are] forms of informational complexity" (Douglas 1986: 48) that enculturate norms and practices both inside and outside their physical forms. Mary Douglas (1986), in her study of institutions, takes a somewhat narrower view than the more critical response from Michel de Certeau (1984), who presents institutions more as cultural, social, and economic forces in tension with individual identity and agency. Given my emphasis on physical spaces and structures, I am drawn to Douglas's more concrete understandings of institutions, while still indebted to a de Certeauian frame of how power operates in and is operationalized by institutions.

In particular, I find de Certeau's (1984) dynamics of strategies and tactics useful in describing the ambitions and experiences of bookmobiles. When I use the term tactics, it is in the specific de Certeauian sense of describing a tension between individual agency and will against the dominating force of institutional (infra)structures. Strategies are the predictable, ordered structures of institutions, and tactics are the highly individualized habits and paths that take shape within. As a concept, tactics offer a way of thinking about forms of appropriation and play as they arise against institutions and within infrastructures.

One final caveat before I turn to a description of my bookmobile fieldwork — I have described bookmobiles as sites of social connectivity, reflecting my views of libraries as a beneficial social good. But libraries also have less positive, more hegemonic connotations. For example, Sanford Berman (1971) authored a powerful critique of the ways that library classification schemes entrench forms of privilege and power, inspiring an entire generation of critical classification studies (e.g., Drabinski 2013). Libraries have sometimes been undertaken as nation- making projects, often instilling patriarchal, heteronormative values, with library collections sometimes becoming a battleground of moral values (Knox 2015).

I do not want to dismiss these important critiques, although I would argue that they apply to almost any public institution (Althusser 2006). Without denying that bookmobiles can and have engaged in colonialist, elitist, and bourgeois projects of normative capitalism or hegemony, I do not see these tendencies as unavoidable or allencompassing. Indeed, my analytical framework is geared precisely toward thinking about bookmobiles as interventions with the capacity for both conforming to and subverting cultural and political norms.

\section{Haiti's BiblioTaptaps}

Haiti is a country of approximately 10 million people, and the country's founding is generally considered the first instance of a successful slave rebellion resulting in statehood. Despite this proud history, the country has long been wracked by economic and political instability. Haiti was already the poorest country in the Western Hemisphere when a devastating earthquake struck in 2010, killing over two hundred thousand people. From an infrastructural standpoint, approximately 1.5 million people became homeless after nearly three hundred thousand houses were either damaged or destroyed, as were approximately four thousand schools and 60 percent of government and 
administrative buildings (Disasters Emergency Committee 2015). Although significant recovery efforts streamed in from a range of aid agencies, charities, nongovernmental organizations, and state actors, the country continues to struggle with extensive infrastructural damage, a fragile government, and a very weak economy.

I began fieldwork in Haiti after participating in a delegation of activist librarians and information workers in 2013, returning on my own to conduct additional fieldwork in 2014 and 2015 in Port au Prince. During that time, I interviewed bookmobile administrators, librarians, and patrons about a project sponsored by Bibliothèque Sans Frontières (BSF). In the wake of the 2010 earthquake, BSF partnered with a series of local Haitian library organizations - Direction Nationale du Livre, the National Library of Haiti, and Fondasyon Konesans ak Libète (FOKAL) - to establish a bookmobile initiative, which they called BiblioTaptaps.

To understand the local role of bookmobiles in Haiti, it is crucial to understand local infrastructure, particularly in terms of transportation. Lacking an official public transportation system, Haitians instead rely on an informal network of buses and ride sharing, epitomized by the taptap. Taptaps are decidedly a tactical innovation, where drivers modify pickup trucks by installing benches in the flatbed, typically with a large covering on top for protection from the sun. Biblio-Taptaps follow the same essential format as taptaps, with the fundamental difference of swapping books for people. BSF funded three BiblioTaptaps, providing training and materials, but the day- today management was left up to the three local Haitian library organizations mentioned above.

My fieldwork was conducted with the taptap associated with FOKAL, a library and literacy organization in Port au Prince, which has been operating one of the BSF taptaps since 2013. Each taptap holds about a thousand books, roughly split between adult and children's literature. BiblioTaptaps operate five days a week, visiting different cities each day and providing books, reading programs, and Internet access. They serve thousands of people each month. In addition to interviewing BSF coordinators of the BiblioTaptap program, I spoke with librarians and patrons about the daily operations and experiences of these bookmobiles as they move through Haitian landscapes.

When BiblioTaptaps arrive in a park, square, or field, they assemble a crowd; it often seemed that they provided a temporary organizing principle in what otherwise felt like a constantly changing, somewhat chaotic, social setting. Unemployment in Haiti is quite high and school enrollment is low (UNICEF 2013a), meaning that large numbers of people are looking for ways to pass time. In addition to providing media and programing, BiblioTaptaps offer a meeting point and ways to alleviate boredom.

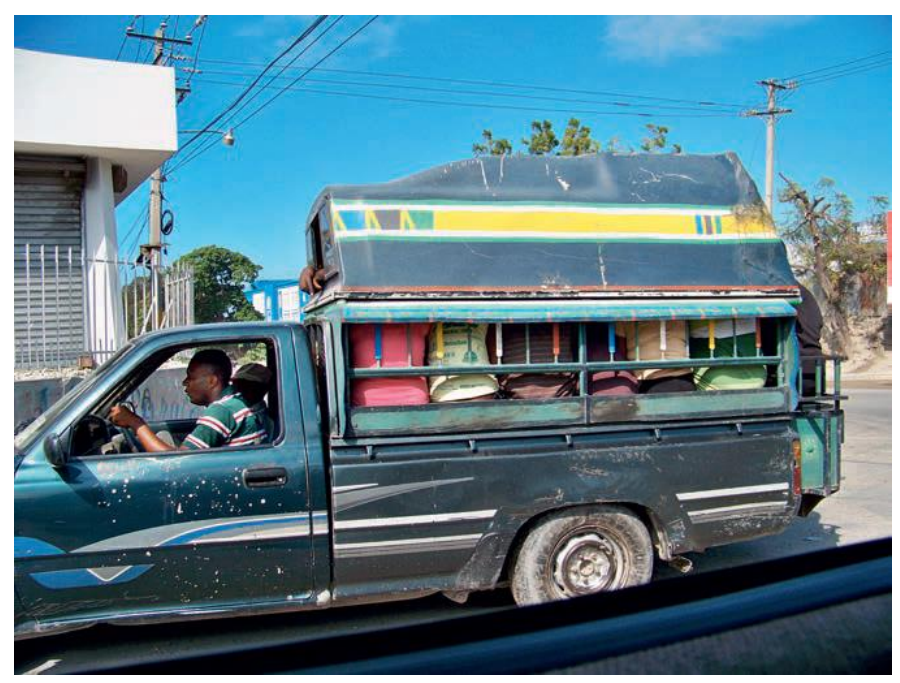

Figure 1 Brightly colored taptaps are a fixture on Haitian roads and a crucial mode of transportation in a country with minimal infrastructure. Photograph by Eric Goldhagen 


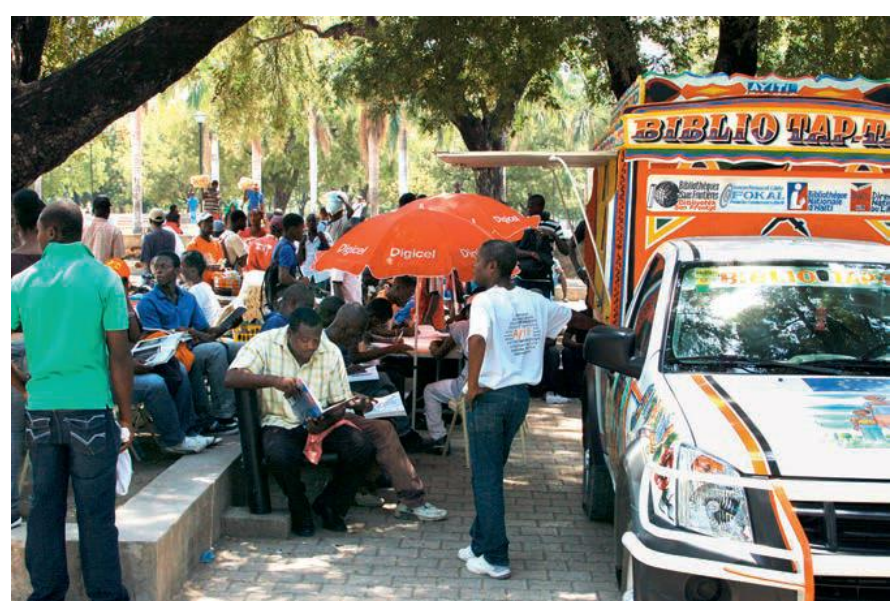

Figure 2 Libraries Without Borders (LWB) first initiated the BiblioTaptap project in 2011, following the devastating earthquake that struck Haiti in January of 2010. In 2015, LWB transitioned responsibility for the taptaps to local library organizations, and the taptaps continue to serve local populations, providing books, programming, and Wi-Fi hotspots. Photograph courtesy of Libraries Without Borders

\section{Haifa's Palestinian Bookmobiles}

In April 2015, I joined a delegation called Librarians and Archivists with Palestine, traveling to Palestine and Israel to support different Palestinian organizations related to libraries and archives. We spent over a week meeting with different librarians and archivists, mostly in the West Bank. I met with a small group of librarians who worked on a bookmobile that operated primarily in Haifa, but it also traveled to other cities in Israel. With a population of just under three hundred thousand people, Haifa has a reputation as one of the most integrated cities in Israel as far as Jewish and Arab relations, with Arabs constituting 10 percent of the city's population (UNICEF 2013b).

Despite this reputation for diversity and tolerance, the Palestinians I met in Haifa were starkly critical of their lack of civil liberties. In the specific context of libraries, books, and language, Palestinians noted a diverse range of issues: some spoke of the difficulty of gaining access to archival collections of Palestinian culture and history, which were almost always housed in Israeli institutions and largely inaccessible to most Palestinians; booksellers described the elaborate obstacles for getting books in Arabic into the country; parents, educators, librarians, and others expressed concerns about declining literacy in Arabic among Palestinian youth.

During my group's meetings with different educators, booksellers, authors, and librarians, I spoke with a bookmobile worker who had been operating for the past several years in Haifa. The bookmobile was geared toward elementary school children; in some cases it partnered with schools to supplement their collections of books in Arabic, and in other cases it provided more of an after- school activity service. I was unable to see the bookmobile in operation; I was only able to conduct interviews with the librarians running it, as well as other librarians and teachers who work with the bookmobile on a regular basis. The bookmobile is possible only because of a dedicated group of volunteers (comprised mostly of former or underemployed teachers rather than librarians) and their connections to a network of Arabic schools and nonprofit organizations. These networks shape processes of acquiring books as well as decisions of where and when the bookmobile operates.

\section{The Tactical Work of Bookmobiles}

In talking to bookmobile librarians and patrons, I learned about the mobile libraries' physical and conceptual makeup and their economic, interinstitutional provenance. I watched how BiblioTaptaps moved through space and navigated obstacles and positioned themselves in public squares. Reflecting on these dialogues and observations, I offer four conceptual lenses for understanding institutional relationships to infrastructure, brought into relief by bookmobiles as they traverse social and geographic terrains: tactical mobility; language and/as structures; resilient materiality; and rhizomatic archiving.

\section{Structures of Mobility}

In the very act of navigating space, bookmobiles render visible the accessibility of roads, where roads go, what and whom they connect. In arguing that mobile assemblages reveal the limits of transportation infrastructure, it is important to note that not all bookmobiles are created equal or, more precisely, they are not all equally tactical. 
BSF administrators described an earlier bookmobile attempt in response to Haiti's devastating 2010 earthquake, in which the American Library Association (ALA) sought to bring bookmobiles to Haiti. The vehicles the ALA had in mind, however, were based on models familiar in the United States, where it is common to covert school buses or even semitrucks. In the best of times, these vehicles could never navigate Haitian roads, let alone after the massive earthquake damage. Without wanting to disparage the undoubtedly well-intentioned efforts of the ALA's initiative, it is difficult to imagine a more symbolic (and colonialist) representation of disjuncture between local knowledge and external perceptions of infrastructure and needs.

In contrast, taptaps have a long history of managing the complexity of Haitian roads and are deeply familiar to residents of urban Haiti. In 2014 I interviewed BSF coordinators who had originally proposed taptaps as vehicles for their bookmobiles and was told that the idea had sprung both organically and collectively, that "it just felt obvious." Yet the obviousness of taptaps requires familiarity with local infrastructure. After all, it was just as obvious to librarians in the United States that semitrucks and school buses were reasonable vehicles to bring their plans for mobility to fruition.

As a convergence of people, institutions, and media, bookmobiles elicit a particular relationship to infrastructure that recognizes the ways in which people themselves are infrastructure. For AbdouMaliq Simone (2004: 411), "people as infrastructure describes a tentative and often precarious process" of remaking space. Bookmobiles correspond quite literally to these tenets, in that bookmobiles are only mobile when operated by people and only become libraries (rather than, say, bookstores) because of the professional labor of librarians. Moreover, bookmobiles tend to operate in tentative, improvisational ways, which is not to say that they do not involve intense amounts of planning and training (see Brown 1967; Sexton 1961), but only to say that they regularly encounter unforeseen obstacles, both social and spatial.

BiblioTaptaps' tactical relationship to infrastructure dovetails with Simone's (2004) arguments that infrastructures have to be contextualized in terms of precarity and impermanence. Taptaps themselves are a remarkably concrete example of an assemblage that takes shape in precarity, a tactical form of transportation that privileges mobility over comfort or speed. As assemblages, BiblioTaptaps rely on local practices of mobility to distribute resources across a heterogeneous terrain of infrastructure.

Mobility through transportation infrastructure is also crucial in the context of an explicitly Palestinian project within Israel. In my conversation with Palestinian librarians about their everyday lives as well as in many other accounts of average Palestinians, mobility is deeply politicized. This is particularly true for Palestinians in the West Bank and (even more so) in Gaza, but it is also experienced by Palestinians in Israel, whose abilities to move around within Israel are shaped by different forms of precarity, from incredibly arbitrary demands for paperwork and identification to civic disenfranchisement to experiences of physical intimidation and violence (see American Anthropological Association 2015).

Although roads are physically much better maintained and more easily traversed in Haifa than in Port au Prince, the ability to move is nevertheless precarious, in the sense that Palestinians are subject to forms of heightened surveillance and limited mobility. These difficulties of movement are as applicable to books as to people. In talking about the role of their mobile library in Haifa, librarians emphasized autonomy, not only in terms of collecting Arabic- language texts, but also in terms of being able to choose their patrons, at least as far as determining the schools and neighborhoods where they operated. When other kinds of physical movements are heavily neglected and restricted, the ability to circulate books with a vehicle that itself circles in and through the city is an important symbol. Indeed, as I spoke with librarians, teachers, and booksellers, I was struck by the nearly identical language used to describe restrictions of books and bodies. Representative of key themes in these conversations were remarks from a librarian at Birzeit University in the West Bank: "We don't have freedom of information, and we struggle to give the right education and information to Palestinian people. That's our issue." In a context of highly restricted movements for Palestinians (and their books), the Haifa bookmobile becomes important as a physical instantiation of Arabic language and texts that move and circulate.

Both cases resonate with Simone's (2004: 408) description of people as infrastructure, in that bookmobiles both respond to and reproduce conditions of flexibility and uncertainty: "The accelerated, extended, and intensified intersections of bodies, landscapes, objects, and technologies defer calcification of institutional ensembles or fixed territories of belonging." For Simone's Johannesburg, this deferred calcification continually opens up new 
affordances of social performance and alliances. By navigating physically and politically obstructed roads, bookmobiles in Haifa and Port au Prince defer certain kinds of calcification, demonstrating institutional flexibility against a backdrop of psychosocially charged infrastructure.

\section{Structures of Language}

Bookmobiles are more than vehicles because of what they carry - media, programming, and expertise. Here I want to think through the choice to move books and media, rather than, say, food or medical equipment. As mobile libraries, bookmobiles are deeply invested in literacy and language. In both Port au Prince and Haifa, structures of language emerged as salient not only through a historical or political lens but also in terms of media and representation. Haitians and Palestinians have specific relationships to language that make bookmobiles more important as they navigate not only physical infrastructure but also the politics of discourse. For Haitians, the circulation of texts in Creole reflects a commitment to indigenous identity and postcolonial politics. Palestinians have a similar investment of the circulation of Arabic books and texts, particularly in the context of their own movements being subject to restriction and control.

Although Creole and French have been the official languages of Haiti since 1987, at least 95 percent of the population speaks only Creole (DeGraff and Ruggles 2014). Yet it is almost impossible to obtain books written in Creole in Haiti, both because Haitian Creole was only formalized as a written language in the 1970s and because the country lacks an established local publishing industry. French- language books are far more accessible; however, as is the case in many Caribbean countries, Haiti's relationship to French as a language is laden with lingering anticolonial resentment. Reflecting an awareness of these tensions, BiblioTaptap librarians have made a concerted effort to gather books in Creole as a means of supporting not just literacy but literacy in Creole.

Similarly, a core focus for the Palestinian bookmobile has been fostering a commitment to literacy in Arabic. According to the librarians I met, it is increasingly common for young people (particularly in Israel and the diaspora) to speak but not read Arabic, and part of how bookmobile librarians described the telos of bookmobiles is as giving children access to books in their own language. In these contexts, the decision to offer books in a particular language is just as important as, or perhaps even more important than, the particular titles selected for inclusion.

The political work of bookmobiles is tied not only to the circulation of media but also to structures of language, where the collection of books in a particular language takes on a political valence. On a bookmobile, circulation refers both to checking out books and to bringing books from place to place. There is an important function of public display that manifests in bookmobiles as they move not just from person to person but from place to place. Within a library, the circulation of books is fairly private, typically contained between the library and the patron (although for important exceptions, see Carpenter 2015; Thielman 2016). In contrast, bookmobiles convene a public, assembling a body of users and readers, however temporary. Within that temporary public, there is a political undercurrent to the circulation of books written in the local language; in de Certeauian (1984) terms, the language of tactics rather than strategies.

\section{Material Resilience}

Offering books written in local languages is not only a matter of symbolism; it is also a matter of materialism. In talking to bookmobile workers in Haifa, I was struck by the emphasis they placed on tactility, the stated importance of giving children a physical experience with their language. As one librarian explained: "Computers and tablets break, but books, they last! Kids can hold them, play with them, they can be rough." Contexts of precarity sharpen the importance placed on materiality by bookmobile librarians. Given enduring forms of crisis, threatening the stability of objects and people, books that circulate bear witness to their own use and survival.

Books are meant to be durable. Despite talk of their near obsolescence, books are remarkably easy to use and distribute, and they can survive many rounds of use. The life spans of laser discs, floppy disks, CD- ROMs, and DVDs as formats are typically measured in decades, whereas books can still be read after centuries. Of course, not all books (and perhaps particularly not bookmobile books) are meant to last for centuries. But even if library books are not always meant to last, they are meant to be used and to be used in a context of everyday life as opposed to special, elite, or extraordinary contexts. Even in Haiti, where books are expensive and difficult to source, printed media is still more affordable and less fragile than a laptop or tablet. 
The materiality of bookmobile texts matters in signifying resilience. Above, I argued that media circulation takes on political meaning as a manifestation of language connecting people, reader to reader. Language is always political, but the postcolonial contexts of Haitians and Palestinians underscore the capacity of language to reflect membership and belonging. Even without record- keeping artifacts like call slips and catalog cards, library books bear the residue of use in dog-eared corners and marginalia or simply as observed in the flow of books being checked in and out. This accumulation of use in a physical, circulating artifact offers a material yet powerfully symbolic form of resilience. Stephen Graham and Simon Marvin (2001: 18), in their book on networked technology and urban landscapes, argue that urbanists and architects have "tended to focus overwhelmingly on the designed spaces within building envelopes, rather than the networked infrastructures that knit buildings together, binding and configuring the broader spaces of metropolitan life." Although bookmobiles may be similarly looked over as both figurative and literal vehicles of institutional technology, they knit people and buildings together in webs of media and language. This knitting together is all the more important in circumstances where risk pervades over the movement of people, due to fragile infrastructure or political pressure.

There is a risk of naive romanticism or blithe indifference in suggesting that people in circumstances of substantial hardship and oppression could draw comfort from bookmobiles as a symbol of anything, perhaps particularly resilience. Rather than suggesting that bookmobiles overcome harsh or restrictive conditions, I am arguing that part of their political power stems from the capacity to enact the physical circulation of books and media in contexts where the circulation of people is difficult or dangerous.

\section{Deconstructing Archiving}

The final component of mobile infrastructure brought into relief with bookmobiles is what I call a capacity for rhizomatic archiving, which requires a shift from a librarian to an archivist ethic. Above, I voiced a librarian perspective (and indeed the first law of library science — see Ranganathan 1931) that books are for use. This stands in contrast to an archival telos of preservation. Without diverting into a long exposition on the professional or existential differences between libraries and archives as institutions, I want to stress that their relationships to media are related but divergent. Libraries (tend to) emphasize access and circulation and archives (tend to) emphasize description and control. People in circumstances of crisis need books to read and access to information, but they also need to be able to preserve their histories and perspectives. Bookmobiles are rarely charged with this task, but they could be in significant and provocative ways, promoting archival projects as well as librarian resources.

Of the many conversations I had with librarians and archivists in Palestine, I was particularly moved by a comment that an academic working with the Institute for Palestine Studies in Ramallah made to our group: "In the case of Palestine, fragmentation makes it impossible to think of a national archive, so there's a preference for a network of archives, more of a national archival activity rather than a national archive." By fragmentation, this researcher referred to the split of Palestinians between the West Bank and Gaza, as well as between those within Israel and the Palestinian diaspora.

In addition to social fragmentation, Palestinian relationships to books and archival materials include a fear of destruction, as indicated by another archivist, who lived and worked in the West Bank: "In any invasion, the library could be destroyed, the computers could be destroyed - so there's a constant fear. .. A Archiving is more than history, it's our lives ... to prove that we were here, [the land is] ours still." Given the long- standing dispersal of Palestinians and the repeated destruction of and restricted access to Palestinian historical materials (Hatuqa 2013), these comments emphasize archives not as an institution but as a practice that could be called rhizomatic archiving.

Historically, the value of archives has been tied to institutional centrality, the gathering of a discrete set of materials in a single site. In contrast to this vertical and highly structured model, rhizomatic archiving refers to a horizontal network, in keeping with Gilles Deleuze and Félix Guattari's (1988) understanding of rhizomes as a distributive network in contrast to rigid, formal hierarchies. Moreover, rhizomatic archiving is not reliant on a single site; rather, it is a practice. In contexts of fragmentation and discontinuity, bookmobiles both reflect and respond to a desire to disperse activity geographically. Indeed, rhizomatic archiving can be thought of as a more formal means of gathering the connections, conversations, and ephemera that coalesce around the everyday operations of bookmobiles. 
Although inspired by conversations with Palestinian archivists and researchers, I would also draw connections between ethics of rhizomatic archiving and post-earthquake Haiti. When significant historical and cultural artifacts from museums and schools as well as homes and places of business have been destroyed, producing a sense of community history through collective archiving is both recuperative and emancipatory. With their continual movement and social connectivity, Biblio- Taptaps are remarkably well suited to projects of collective history and archiving the everyday.

Decentralization is in fact key to how BiblioTaptaps were conceived in initial grant requests to fund them. BSF listed two specific objectives of the project, the first to provide "more open access to libraries and books as a core community social service" and the second to "promote the decentralization of cultural infrastructure and interactions between state and non- state actors in Haiti" (LWB 2017). Much like Palestinian archivists who want to decentralize archival collection development work across a population, BiblioTaptaps were from their inception envisioned as distributing tools and resources of cultural production.

Bookmobiles are deeply rhizomatic, with an ethos of mobility and a telos of connectivity. These functions are important not just because they are more equipped to traverse infrastructure via tactics that elude those institutions that can only operate strategically, but (as noted above) because this very movement is a tactic of resistance. I should clarify that neither of the bookmobiles I have studied are currently engaged in the kind of archival work I am describing, but I would argue that (1) they are already operating as an informal archive of reading habits and practices and (2) there is potential for them to take on archival and ethnographic work, should they so choose. I see rhizomatic archiving as a practice that echoes what bookmobiles already do and, in fact, what they represent: a productive response to and representation of fragmentation, where mobility is a tactical communication of institutional values and ethics that can moreover facilitate collective practices of language and memory.

\section{Bookmobile Imaginaries for Institutions and Infrastructure}

A defining characteristic of postindustrial, capitalist society concerns the destabilization of both public and private institutions. This destabilization may be experienced beneficially by the rich, who gain privileges of working remotely and access to sophisticated tools and platforms. In striking contrast, for the poor, destabilization often means decreasing job security and diminished access to forms of services and support (Caldeira and Holston 2005). These disparities cannot be addressed, let alone mitigated, at the level of abstraction; instead, we need grounded models for thinking more precisely and concretely about distributions of power as institutions become less stable and more mobile.

Rather than looking at how institutions distribute goods and materials across complex (and violent) networks (e.g., Cowen 2014), I have looked to small- scale instances of institutions on the move, reading bookmobiles as manifestations of decentralized social institutions. The work of bookmobiles cannot be reduced to the act of passing out books or even to producing networks of people, texts, and technologies. The political capacity of bookmobiles, as mobile institutions, can manifest along axes of transportation, language, and memory. Drawing on Arjun Appadurai's (2015) critique of actor- network theory (ANT), I want to claim these capacities as different forms of mediation, the thickness in the edges between institutions and infrastructures, media and roads, people and memory.

ANT has been incredibly generative in accounting for the role of technology within the social landscape, yet it has been critiqued for decontextualizing the sociotechnical networks under study. In particular, Appadurai's (2015) concept of mediants offers a critique of ANT as an insufficiently robust theory for accounting between network nodes. While Appadurai agrees that sociological work should account for technologies in describing social worlds, he argues that some technologies are more crucial, tactical, or ideologically loaded than others. There is an explanatory depth in mediants, in that they provide a descriptive layer for relationships within and constituting an assemblage. In network terminology, ANT insists on counting both people and things as nodes that constitute a network, while mediants provide a social accounting for the edges that link nodes as well as for nodes themselves. In looking at the sociotechnical fabrics in which bookmobiles operate and of which they are a part, mediants offer an important layer of critical depth, allowing a more precise ANT framework for asking about what it is that bookmobiles do in terms of materiality and politics.

I have argued that in the context of bookmobiles, these mediant characteristics include flexibility within existing infrastructure, the capacity to translate, resilient materiality, and rhizomatic possibility of DIY preservation. This list 
is surely not exhaustive; my purpose in teasing out these mediant capacities has been to develop a more robust account of decentralized institutions, one that acknowledges both the sociotechnical depth and political valences of institutional mobility within infrastructures.

As a way of extending my arguments beyond the specific case of bookmobiles, I close with some final implications for thinking about mobile institutions. My arguments expand on the claim that what is at stake in bookmobiles is the capacity for reimagining relationships to and between institutions and infrastructure. These acts of reimagination contain critiques of sociotechnical arrangements as they are and, at the same time, activist futures of how they could be otherwise.

\section{Reimagining Institutions}

The loosening of institutional stability has troubling implications for social justice and economic parity, as noted above. Yet literal manifestations of mobilizing institutions may present powerful opportunities for confronting and reimagining relationships to and expectations of institutions and communication. I mean this both in terms of how institutions communicate their interests and ideologies and in terms of how (or whether) individual people and communities can speak back to state and corporate actors.

As social institutions, libraries are valuable (and increasingly rare) public sites of communication and community. I follow Shera (1970) in viewing the communicative function of the library as vital to its role in supporting local communities. Librarians communicate with patrons, and libraries themselves communicate local values and ethics in terms of the books they catalog (Berman 1971), the policies that govern them (Lingel 2012), and the spaces they provide (Mattern 2014). Thus the communication work of libraries takes place quite literally between patrons and library staff, while answering reference questions and recommending books, but communication also takes place less directly, through policies guiding collection development and daily operations, for example.

When libraries become mobile, packing up books and technologies, developing literacy and entertainment programming, and taking them on the road, communication manifests in both content (media as resource) and form (mobility as service). To make a library mobile is to provide materials that communicate, even as mobility itself communicates spatial and temporal flexibility, with contingent provocations for theories of infrastructure as well as institutions. In contexts of crisis, relationships between bookmobiles, institutions, and infrastructure often become more complex and more overtly political, even as their services also become more necessary.

The communicative functions of libraries and bookmobiles are instructive in the context of reimagining relationships to institutions. Beyond being a site where dialogue between people or between people and texts takes place, mobility communicates the structural affordances and commitments of an institution. In the fieldwork I conducted, these commitments emerged most clearly in the context of language, of deliberately including books and media written in Creole and Arabic as a reflection of political solidarity. Rhizomatic archiving is in itself a platform for communication about the experiences and values of a community's everyday life. Using these dynamics and examples, we can see how bookmobiles encourage a mindfulness of how institutions communicate, the divergences between formal and informal communication, and the willingness to accommodate (or even foster) a plurality of voices in communication.

\section{Reimagining Infrastructure}

Penny Harvey and Hannah Knox (2012) have argued that infrastructure projects like roads are sites of imagination and enchantment, in which political ideologies and material processes are deeply intertwined. Libraries are also sites of imagination and enchantment (Chrostowska 2015), providing structures for encountering new ideas and pursuing threads of interest and inquiry. When bookmobiles navigate infrastructure, the physical points of connection (or collision) between vehicle and street become evaluative statements of the roads themselves, a confrontation between tactical and strategic narratives. Just by their rarity, bookmobiles call attention to what is and isn't expected on local roads. Their specific manifestations as school bus or taptap, semitruck or river barge, can demonstrate familiarity with and implicit criticisms of infrastructure.

The institutional provenance of bookmobiles is crucial here - any vehicle reveals the limits of the roads that it traverses. But in the choice of a vehicle, the act of rendering a library mobile becomes a statement about 
infrastructure. Moreover, the specific choices of what shape a bookmobile takes - bus or taptap, grocery cart or donkey - is an opportunity to acknowledge and respect local knowledge of infrastructural limits and capacities.

When physical infrastructure is minimal or in crisis, networks of people and their relationships to infrastructure become more legible, salient, necessary, and symbolic. As bookmobiles move through roads and navigate local terrain, their physical form reflects how local roads are imagined. They also produce an imagined narrative of mobility that becomes salient and politically compelling in contexts where other forms of mobility are restricted. As Brian Larkin (2013) notes, not all infrastructure is invisible until broken - sometimes it is intentionally and politically visible. Bookmobiles may help to communicate broken infrastructure, but their very mobility also communicates fragmentation, calling into question both institutional and infrastructural fixity. Writing about the tendency of Johannesburg residents to be _flexible and improvise, Simone (2004: 424) argues that "this sense of preparedness, a readiness to switch gears, has significant implications for what residents think it is possible to do with the city." Bookmobiles have similarly significant implications for what readers, users, librarians, and passersby think it is possible to do within infrastructure.

I have maintained a divide between institutions and infrastructure throughout this essay, setting up a division that is often experienced with much more blurriness. The increasing privatization of public utilities and resources makes it legally and phenomenologically tricky to assign clear distinctions between public and private when at a park or on a subway. Yet these distinctions matter deeply at protests occupying parks or streets, and during railway strikes and in trying to figure out who should repair what or pay restitution to whom in cases of natural disaster or political oppression. Insisting on differences between institutions and infrastructure, even when they have shared political objectives, matters. So do libraries and their tactical, rhizomatic, serious- and- at- the- same- time playful offshoots, bookmobiles. As sociotechnical assemblages, bookmobiles offer a way of thinking with and through these

differences in ways that can help us reevaluate the need for and operations of public institutions as well as the limits, affordances, and inequalities of infrastructure.

\section{References}

Althusser, Louis. 2006. "Ideology and Ideological State Apparatuses (Notes towards an Investigation).” In The Anthropology of the State: A Reader, edited by Aradhana Sharma and Akhil Gupta, 86-111. Malden, MA: Blackwell.

American Anthropological Association. 2015. "The Task Force on AAA Engagement on Israel- Palestine: Report to the Executive Board." Arlington, VA: American Anthropological Association. s3.amazonaws.com/rdcmsaaa/files/production/public/FileDownloads/151001-AAA-Task-Force-Israel-Palestine.pdf.

Appadurai, Arjun. 2015. "Mediants, Materiality, Normativity." Public Culture 27, no. 2: 221-37.

Attig, Derek. 2014. "Here Comes the Bookmobile: Public Culture and the Shape of Belonging." PhD diss.,

University of Illinois at Urbana- Champaign.

Batchelder, Michael. 2015. "Not Your Parents' Bookmobile." Bellevue Leader, June 24.

www.omaha.com/sarpy/bellevue/not-your-parents-bookmobile/article_7d56a8d5-4bc9-5617-b8e6cc88f57a379a.html.

Berman, Sanford. 1971. Prejudices and Antipathies: A Tract on the LC Subject Heads Concerning People. Metuchen, NJ: Scarecrow.

Brown, Eleanor Frances. 1967. Bookmobiles and Bookmobile Service. Metuchen, NJ: Scarecrow.

Caldeira, Teresa, and James Holston. 2005. State and Urban Space in Brazil: From Modernist Planning to Democratic Interventions. Malden, MA: Blackwell.

Carpenter, Zoë. 2015. "Librarians versus the NSA.” Nation, May 6. www.thenation.com/article/librarians-versusnsa.

Chrostowska, S. D. 2015. "Shelf Lives: On Nostalgic Libraries.” Public Culture 28, no. 1: 9-21. Cowen, Deborah. 2014. The Deadly Life of Logistics: Mapping the Violence of Global Trade. Minneapolis: University of Minnesota Press.

Dar, Mahnaz. 2014. "School Librarian Fights Summer Slide with School Bus-Turned-Bookmobile." School Library Journal, July 30. www.slj.com/2014/07/industry- news/school-librarian-fights-summer-slide-with-school-busturned-bookmobile.

de Certeau, Michel. 1984. The Practice of Everyday Life. Berkeley: University of California Press.

DeGraff, Michel, and Molly Ruggles. 2014. "A Creole Solution for Haiti's Woes.” New York Times, August 1. www.nytimes.com/2014/08/02/opinion/a-creole-solution-for-haitis-woes.html. 
Deleuze, Gilles, and Félix Guattari. 1988. A Thousand Plateaus: Capitalism and Schizophrenia. Translated by Brian Massumi. London: Athlone.

Disasters Emergency Committee. 2015. "Haiti Earthquake Facts and Figures." www.dec.org.uk/articles/haitiearthquake-facts-and-figures.

Doctorow, Cory. 2010. "Fox News Advocates Shutting Down Public Libraries.” Boing Boing (blog), June 30. boingboing.net/2010/06/30/fox-news-advocates-shtml.

Douglas, Mary. 1986. How Institutions Think. Syracuse, NY: Syracuse University Press.

Drabinski, Emily. 2013. "Queering the Catalog: Queer Theory and the Politics of Correction.” Library 83, no. 2: 94111.

Elton, Cassandra. 2015. "Breaking Down Invisible Barriers: Using Bookmobiles to Facilitate Library Outreach in Urban and Suburban Communities." B Sides 6. ir.uiowa.edu/bsides/40.

Finn, Megan, and Elisa Oreglia. 2016. "A Fundamentally Confused Document:Situation Reports and the Work of Producing Humanitarian Information.” Proceedings of the Nineteenth ACM Conference on Computer-Supported Cooperative Work and Social Computing, 1349 - 62. New York: ACM.

Graham, Stephen, and Simon Marvin. 2001. Splintering Urbanism: Networked Infrastructures, Technological Mobilities, and the Urban Condition. Brandon, VT: Psychology Press.

Harvey, Penny, and Hannah Knox. 2012. “The Enchantments of Infrastructure.” Mobilities 7, no. 4: 521 - 36.

Hatuqa, Dalia. 2013. “Israel’s 'Great Book Theft' Unravelled.” Al Jazeera, January 29. www.aljazeera.com/indepth/features/2013/01/201312114556875749.html.

IFLA (International Federation of Library Associations and Institutions). 2002. The Donkey Drawn Mobile Library Services in Zimbabwe, August 6 - 13,2001: Report on the Assessment of Non- motorized Mobile Libraries. IFLA Round Table on Mobile Libraries. The Hague: IFLA.

Irani, Lilly C., and M. S. Silberman. 2013. "Turkopticon: Interrupting Worker Invisibility in Amazon Mechanical Turk." In Proceedings of the SIGCHI Conference on Human Factors in Computing Systems, 611 - 20. New York: ACM.

Knox, Emily. 2015. Book Banning in Twenty-First-Century America. Lanham, MD: Rowman and Littlefield.

Larkin, Brian. 2013. "The Politics and Poetics of Infrastructure.” Annual Review of Anthropology 42: 327 - 43.

Lingel, Jessa. 2012. "Occupy Wall Street and the Myth of Technological Death of the Library." First Monday 17, no. 8. firstmonday.org/ojs/index.php/fm/article/view/3845/3280.

Losowsky, Andrew. 2013. "Why It's Time to Speak Up for Our Libraries."Huffington Post, July 29. https://www.huffingtonpost.com/andrew- losowsky/libraries-in-crisis-introduction_b_1096030.html.

LWB (Libraries Without Borders). 2017 "BiblioTaptap: Bookmobiles for Haiti." https://www.librarieswithoutborders.org/actions/bibliotaptap-book-mobiles-for-haiti/ (accessed October 20, 2017).

Mattern, Shannon. 2014. “Library as Infrastructure.” Places Journal, June. placesjournal.org/article/library-asinfrastructure.

Mazzarella, William. 2010. "Beautiful Balloon: The Digital Divide and the Charismaof New Media in India." American Ethnologist 37, no. 4: 783 - 804.

MIT Technology Review Staff. 2005. “The Death of Libraries?” MIT Technology Review, May 1. www.technologyreview.com/s/404030/the-death-of-libraries.

Pew Research Center. 2014. "Libraries in the Digital Age." Internet and American Life Project. Washington, DC: Pew Research Center. www.pewinternet.org/2014/08/18/public-library-engagement-in-the-unitedstates/libraries_ebooks_patrons_homepage- 2 .

Radford, Marie, and Gary Radford. 1997. "Power, Knowledge, and Fear: Feminism, Foucault, and the Stereotype of the Female Librarian.” Library Quarterly 67, no. 3: 250 - 66.

Ranganathan, Shiyali Ramamrita. 1931. The Five Laws of Library Science.Madras: Madras Library Association; London: Edward Goldston.

Sexton, Irwin. 1961. "Bookmobile Operations and the Library System.” Library Trends 9, no. 3: 306 - 21.

Sheller, Mimi. 2013. "The Islanding Effect: Post-Disaster Mobility Systems and Humanitarian Logistics in Haiti." Cultural Geographies 20, no. 2: 185 - 204.

Sheller, Mimi, and John Urry. 2003. "Mobile Transformations of 'Public' and'Private' Life.” Theory, Culture and Society 20, no. 3: $107-25$.

Shera, Jesse Hauk. 1970. Sociological Foundations of Librarianship. Bombay: Asia Publishing House.

Simone, AbdouMaliq. 2004. "People as Infrastructure: Intersecting Fragments in Johannesburg." Public Culture 16, no. 3: $407-29$. 
Skop, Yarden. 2013. "Israel Encouraging Preschool Literacy — Just Not among Arabs." Haaretz, August 14. www.haaretz.com/israel-news/.premium- 1.541469.

Tawil- Souri, Helga. 2011. "Colored Identity: The Politics and Materiality of ID Cards in Palestine/Israel." Social Text 29, no. 2: $67-97$.

Thielman, Sam. 2016. "You Are Not What You Read." Guardian, January 13. www.theguardian.com/usnews/2016/jan/13/us-library-records-purged-data-privacy.

UNICEF (United Nations Children's Fund). 2013a. "At a Glance: Haiti."

www.unicef.org/infobycountry/haiti_statistics.html.

_ 2013b. "At a Glance: State of Palestine." www.unicef.org/infobycountry/oPt_statistics.html.

Wiegand, Wayne. 2011. Main Street Public Library: Community Places and Reading Spaces in the Rural Heartland, 1876 - 1956. Iowa City: University of Iowa Press.

Zyskowski, Kathryn, et al. 2015. "Accessible Crowdwork? Understanding the Value in and Challenge of Microtask Employment for People with Disabilities." In Proceedings of the Eighteenth ACM Conference on ComputerSupported Cooperative Work and Social Computing, 1682 - 93. New York: ACM.

1. Part of Mimi Sheller's (2013) argument is that in contexts of crisis, such as postearthquake Haiti and post- Katrina New Orleans, the ability to move is indicative of certain kinds of privilege. And, indeed, my fieldwork was only possible because of the kinds of privilege afforded to me as a visiting researcher with funding for accommodations, transport, translation support, and guides. I make reflections on mobility throughout this essay that are meant to be a critique of neoliberal celebrations of mobile flows of people and money, but it is also fair to point out that these same capitalist flows enabled parts of my research.

Note:

Jessa Lingel is an assistant professor at the Annenberg School for Communication at the University of Pennsylvania, where she studies digital culture and technological distributions of power. A former librarian, she is currently a John W. Kluge Fellow in Digital Studies at the Library of Congress. 